\title{
Assessment of groundwater quality using statistical methods in the Isly basin (Horst Belt, Morocco)
}

\author{
Soufiane Ziani ${ }^{*}$, Driss Khattach $^{1}$, Jamila Abderbi ${ }^{2}$, Nordine Nouayti ${ }^{3}$, and Mohamed Makkaoui ${ }^{1}$ \\ ${ }^{1}$ Laboratory of Applied Geosciences, Department of Geology, Faculty of Sciences, Mohammed 1st University, Oujda, Morocco \\ ${ }^{2}$ Regional Center for the Professions of Education and Training, Oujda, Morocco \\ ${ }^{3}$ Laboratory of Water and Environmental Engineering, Al Hoceima National School of Applied Sciences PO Box 03, Ajdir Al \\ Hoceima., Morocco
}

\begin{abstract}
The identification of potential sources of groundwater pollution in the Isly basin (North-East Morocco) and the understanding of their spatial variability, in response to certain natural and anthropogenic forcings, were approached through the combined study of ionic ratios and statistical analyses of hydro-chemical data. The results of the Principal Component Analysis (PCA) show that two factors explain nearly $78 \%$ of the variance. Factor 1 is mineral salts $(\mathrm{Cl}$ and $\mathrm{Na})$, and factor 2 is related to alkaline earth metals ( $\mathrm{Ca}$ and $\mathrm{Mg}$ ). The typological structure of the F1 x F2 plan analysis shows four regions according to the nature of pollutants. The contaminations observed for most of the water points could be related to anthropogenic, geological and atmospheric pollution sources.
\end{abstract}

\section{Introduction}

The Isly basin is a region with a semi-arid climate, located in the northeastern Moroccan. It is currently facing a worrying water deficit which has adverse effects on its socio-economic development. Groundwater is the only source of drinking water for the local population. It also contributes to the irrigation of agricultural land [1].

The intensification of agricultural activities, population growth and persistent drought for more than 30 years are factors that contribute, on the one hand, to the decrease in the reserves of the aquifer system in the study area [2] and, on the other hand, to the degradation of the quality of this groundwater.

In this work, we analyzed the geochemical data (major elements and physico-chemical quantities) of thirteen samples taken from various sources, boreholes and wells distributed in the study area.

This was done in order to assess the quality of the groundwater in the Isly basin. Principal Component Analysis (PCA) was used to examine the data and reveal the spatial variability of the groundwater but more importantly to identify possible sources of pollution in the study environment.

\section{Material and Methods}

\subsection{Study area}

Located in northeastern Morocco, between $X=790,000$, $\mathrm{X}=850,000 \quad$ and $\mathrm{Y}=415,000, \quad \mathrm{Y}=460,000$ (Lambert_Conformal_Conic), the study area has a total area of $920 \mathrm{~km} 2$ (Fig.1).

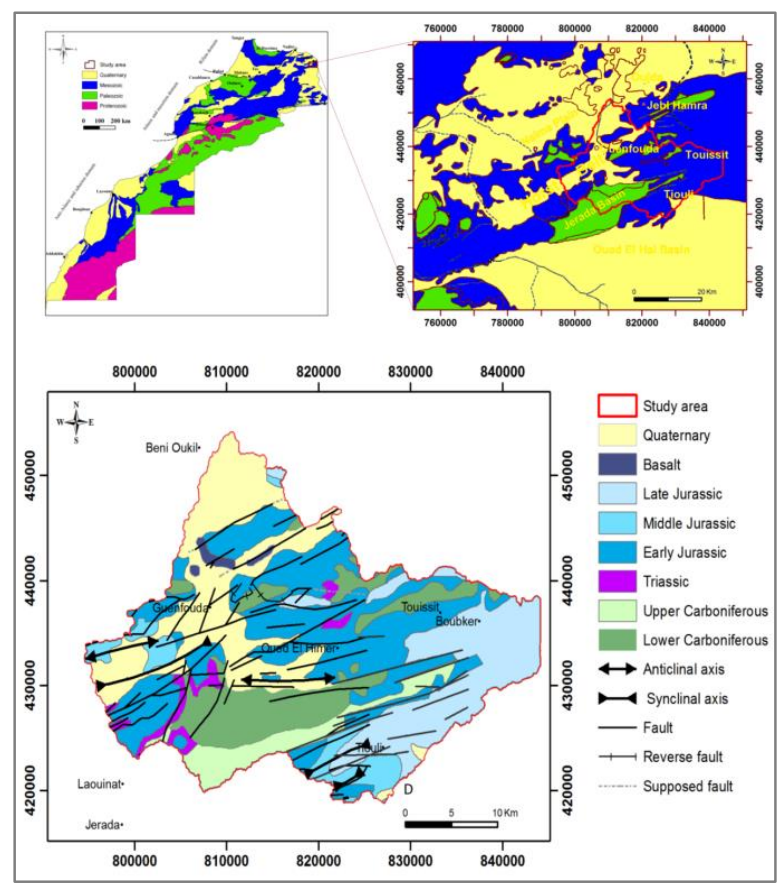

Fig. 1. Location of study area and simplified geological map of the Isly basin (from the geological map of Morocco at 1/1 000 000, Lambert coordinates in $\mathrm{m}$ ).

\subsection{Geological and hydrogeological framework}

The Isly Basin is a hydrogeological entity formed by lands with various geological aspects. However, Mesozoic and Plio-Quaternary formations dominate the stratigraphy of the region [3-4].

Figure 1 shows the main strata of the Isly Basin; the Triassic, which lies at an angular unconformity on the Paleozoic basement, is composed mainly of clays, dolerite basalts, and evaporites [5-6].

*Corresponding author: sziani2013@gmail.com 
The Jurassic series is part of the Lower Triassic-Lias red formations and consists of limestone, dolomite, calcareous marl and siliceous detritus [7-8].

The Jurassic series corresponds essentially to thick limestones and marls. Cretaceous deposits are missing and are only found in the jbel Bou Rhenja.

A thick sequence of sandy clays, sandstones, lacustrine limestones, and sands characterizes the Mio Pliocene strata [9]. Quaternary deposits constitute the last stage of sedimentation; they are represented by calcareous crusts and conglomerate deposits.

The Quaternary series are thin and also show flows of basalt and lacustrine limestone. From a hydrogeological point of view, the Isly basin is located in an arid bioclimatic stage. There is a great seasonality of temperatures with very hot summers and very cold winters [2].

The annual rainfall regime is characterized by two rainy seasons: Autumn and spring [2]; the average annual rainfall is $245 \mathrm{~mm}$ in the upper basin and 100 $\mathrm{mm}$ in the lower basin (Figure. 2).

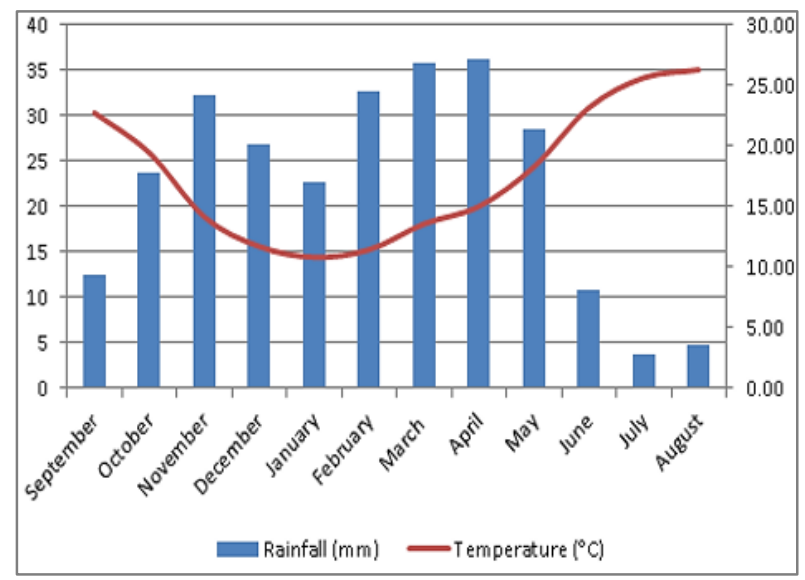

Fig. 2. Correlation of rainfall with temperature and months from Guenfouda meteorological station.

There are two main aquifer systems in the Isly basin: 1) The Plio-Quaternary alluvial aquifer, which contains mainly conglomerates and gravels located along the Isly valley;

2) The Jurassic aquifer containing limestones and dolomites that are often fractured and sometimes karstified [10].

\subsection{Sampling and Analysis}

Water was collected from thirteen wells and springs in the study area (Fig. 3).

Samples were collected manually in 1 liter polyethylene bottles. These bottles were washed three times with distilled water and several times with sampled water.The samples were stored and transported to the laboratory under temperature conditions not exceeding $4^{\circ} \mathrm{C}$.

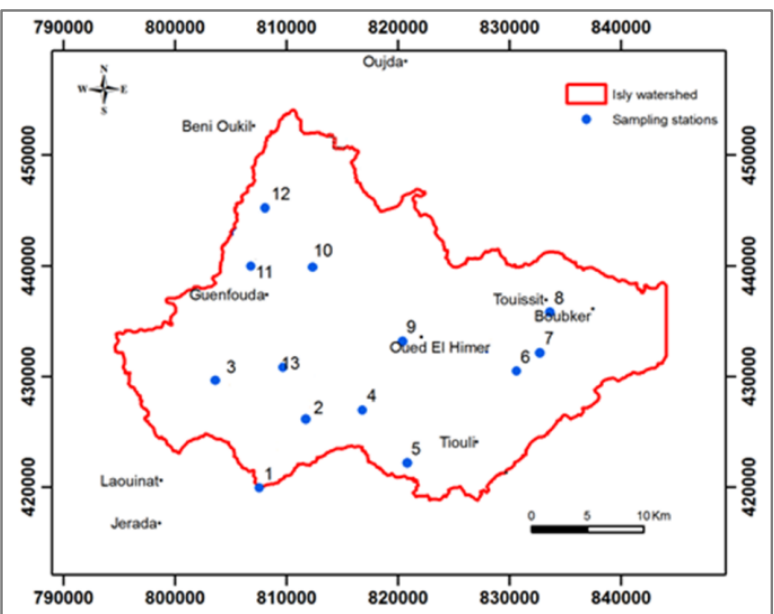

Fig. 3. Distribution of the sampling points of Groundwater in the Isly Basin.

The sampled water points (wells, boreholes and springs) were selected to cover the entire study area. Some physico-chemical parameters $(\mathrm{pH}$, temperature, conductivity) were measured in-situ. Other parameters (chloride $(\mathrm{Cl})$, sulphate $\left(\mathrm{SO}_{4}\right)$, calcium $(\mathrm{Ca})$, magnesium $(\mathrm{Mg})$, sodium $(\mathrm{Na})$, potassium $(\mathrm{K})$, hydrogen carbonate $\left(\mathrm{HCO}_{3}\right)$, dry residue (SM) and water hardness $(\mathrm{WH})$ ) were analyzed in the ONEP-E laboratory.

\subsection{Data processing method}

The processing of chemical analysis results was carried out using geo-statistical methods. Principal Component Analysis (PCA) was performed on data collected from 13 water samples for ten variables: $\left(\mathrm{Cl}, \mathrm{Ca}, \mathrm{SO}_{4}, \mathrm{Mg}\right.$, $\mathrm{K}, \mathrm{Na}, \mathrm{HCO}_{3}, \mathrm{WH}, \mathrm{SM}$ and $\mathrm{EC}$ ). The PCA results are presented in tables and graphs in order to synthesize the information and facilitate their interpretation. This multivariate analysis technique is useful in attempting to identify similarities between water points with respect to their physico-chemical characteristics.

\section{Results and Discussion}

\subsection{Choice of eigenvalues}

Physicochemical data can be processed by the CPA method to obtain various results (Table 1, Table 2 and Table 3). Table 1 shows the eigenvalues, variability, accumulation and the different parameters of the equations for the first two factorial axes F1 and F2 having respectively $50.51 \%$ and $27.46 \%$ or $77.97 \%$ of the information explained. The maximum value of the total inertia is accumulated only by the plane formed by the axes F1 $\times$ F2 (Fig.4). Table 2 shows the contributions of different variables to the development of the main factors. Thus, factor F1 is defined mainly by the mineral salts (sodium and chlorides) which have a close relationship with the dry residue and obviously contribute to the electrical conductivity of the water. This reflects the participation of these ions in the acquisition of the saline charge of the groundwater [11]. 
Table 1. Own values with an inertia of $77.97 \%$.

\begin{tabular}{|c|c|c|c|}
\hline \multirow{2}{*}{ Component } & \multicolumn{3}{|c|}{ Eigen values } \\
\cline { 2 - 4 } & Total & \% of variance & \% cumulative \\
\hline 1 & 5.05 & 50.51 & 42.31 \\
\hline 2 & 2.75 & 27.46 & 77.97 \\
\hline 3 & 0.94 & 9.35 & 87.33 \\
\hline 4 & 0.83 & 8.34 & 95.66 \\
\hline 5 & 0.33 & 3.26 & 98.93 \\
\hline 6 & 0.05 & 0.54 & 99.47 \\
\hline 7 & 0.03 & 0.34 & 99.80 \\
\hline 8 & 0.01 & 0.13 & 99.93 \\
\hline 9 & 0.00 & 0.05 & 99.98 \\
\hline 10 & 0.00 & 0.02 & 100.00 \\
\hline
\end{tabular}

Factor 2 is dominated by alkaline earth elements (calcium and magnesium). The concentration of these two elements strongly influences water hardness.

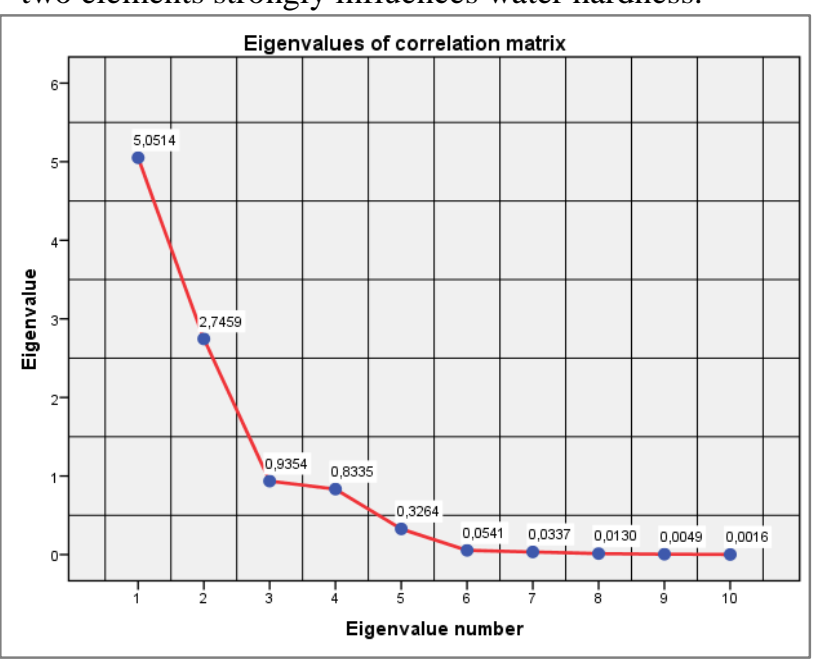

Fig. 4. Projection of the variables on the factorial plan $\mathrm{F} 1 \mathrm{x}$ F2 $(77.97 \%)$

\subsection{Analysis of the distribution of parameters in the plan $\mathrm{F} 1 \mathrm{xF} 2$}

Looking at the correlation matrix between the variables (Table 3), it can be seen that there is a significant correlation between $\mathrm{Ca} * \mathrm{WH}(0.87) ; \mathrm{Mg} * \mathrm{SO}_{4}(0.86)$; $\mathrm{Mg} * \mathrm{WH}(0.89) ; \mathrm{Cl} * \mathrm{SM}(0.00)$.

There is also a lower degree of correlation between variables such as $\mathrm{HCO}_{3} * \mathrm{WH}(-0.49)$; $\mathrm{Na} * \mathrm{Ca}(-0.55)$; $\mathrm{Ca} * \mathrm{HCO}_{3}(-0.37) ; \mathrm{Mg} * \mathrm{HCO}_{3}(-0.48)$ and $\mathrm{EC} *$ $\mathrm{HCO}_{3}$ (-0.42). These different correlations are consistent with each mineralization parameter in the Isly watershed.

Principal Component Analysis (PCA) was conducted to identify trends, correlations and phenomena that influence the distribution of chemical elements in the groundwater of the Isly basin. At the correlation circle formed by the F1 and F2 axes (Fig. 5), variables such as $\mathrm{TH}, \mathrm{Mg}, \mathrm{SO}_{4}, \mathrm{EC}, \mathrm{K}, \mathrm{Cl}, \mathrm{MS}$ and $\mathrm{Na}$ are positively correlated with the $\mathrm{F} 1$ axis and have a variability of $50.51 \%$.
Table 2. Degree of correlation between variables and different axes.

\begin{tabular}{|c|c|c|}
\hline Variables & Factor 1 & Factor 2 \\
\hline $\mathrm{SM}(\mathrm{mg} / \mathrm{l})$ & 0.98 & -0.04 \\
\hline $\mathrm{Cl}^{-}(\mathrm{mg} / \mathrm{l})$ & 0.93 & 0.13 \\
\hline $\mathrm{EC}(\mu \mathrm{S} / \mathrm{cm})$ & 0.84 & 0.47 \\
\hline $\mathrm{Na}(\mathrm{mg} / \mathrm{l})$ & 0.81 & -0.57 \\
\hline $\mathrm{SO}_{4}{ }^{2-}(\mathrm{mg} / \mathrm{l})$ & 0.66 & 0.55 \\
\hline $\mathrm{K}^{+}(\mathrm{mg} / \mathrm{l})$ & 0.46 & 0.16 \\
\hline $\mathrm{WH}(\mathrm{mg} / \mathrm{l})$ & 0.30 & 0.93 \\
\hline $\mathrm{Ca}^{2+}(\mathrm{mg} / \mathrm{l})$ & -0.08 & 0.90 \\
\hline $\mathrm{Mg}^{2+}(\mathrm{mg} / \mathrm{l})$ & 0.55 & 0.77 \\
\hline $\mathrm{HCO}_{3}(\mathrm{mg} / \mathrm{l})$ & -0.04 & -0.64 \\
\hline
\end{tabular}

On the other hand, $\mathrm{Ca}$ and $\mathrm{HCO} 3$ ions are weakly correlated with the F1 factor.

Table 3. Correlation matrix of physico-chemical variables.

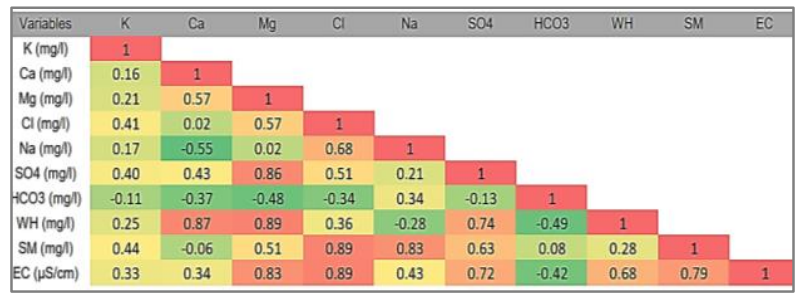

On the F2 axis, with variability of $27.46 \%$, there is a positive correlation between the variables: $\mathrm{Ca}, \mathrm{TH}, \mathrm{Mg}$, $\mathrm{SO}_{4}, \mathrm{EC}, \mathrm{K}$ and $\mathrm{Cl}$. The variables: $\mathrm{SM}, \mathrm{Na}$ and $\mathrm{HCO}_{3}$ are in opposition with the F2 factor.

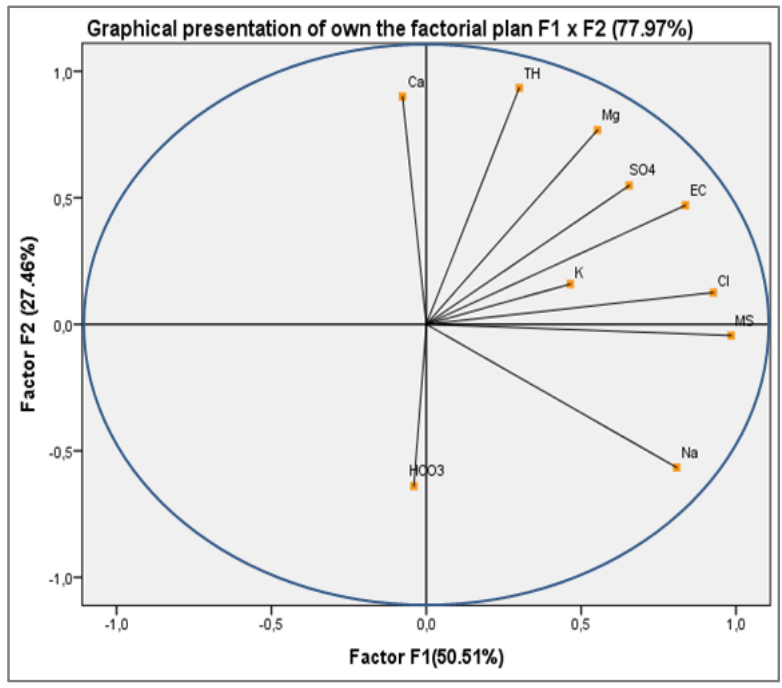

Fig. 5. Graphical presentation of own the factorial plan $\mathrm{F} 1 \mathrm{x}$ F2 (77.97\%).

The graph in Figure 6 shows the distribution of the different sampling points studied in the Isly basin on the factorial plane F1 x F2, which is automatically associated with one of the variables (chemical elements) that give an idea of the water according to the type of pollutant and its degree of contamination. Thus, four groups can be identified: Group I: this group occupies the negative part of axes F1 and F2. It is 
represented by water points E10 and E11. Groundwater in this area originates from Jurassic carbonate formations. This results in high bicarbonate values. The atmospheric contribution (slightly acid rain) to the dissolution of carbonates is highly probable.

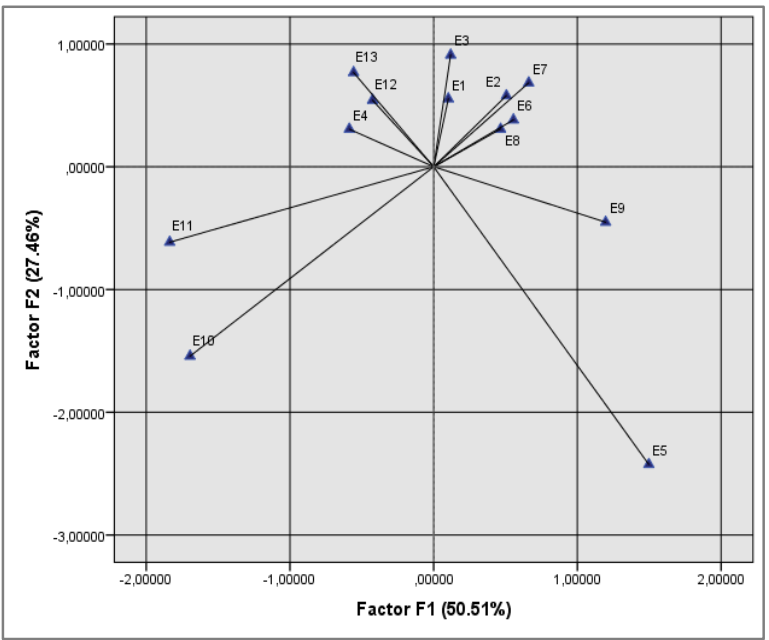

Fig. 6. Representation of water points of the factorial plan F1 $\times$ F2.

Group II: This group represents the negative part of the $\mathrm{F} 1$ axis and the positive part of the F2 axis. It is represented by the water points E4, E12 and E13. The groundwater in this area is polluted by geology due to high calcium concentrations. These high values could be caused by geological salts. This proves that the salinization of the aquifer is very closely related to the recharge processes, especially in a karstic environment.

Group III: the positive part of axes F1 and F2 is represented by samples E1, E2, E3, E6, E7 and E8. The waters are simultaneously contaminated by chlorides, sulphates, magnesium and potassium. Sulphates come from the dissolution of evaporites (gypsum). However, chlorides and potassium are due to anthropogenic pollution of agricultural origin (potassium fertilizer) or/and urban. The high potassium concentrations are also linked to water from basalts, whereas the omnipresence of magnesium can only be explained by a supply from the aquifer of the Jurassic dolomitic limestones. This proves the impact of rock alteration on water chemistry.

Group IV: This group is the positive part of axis F1 and the negative part of axis F2. It is represented by the water points E5 and E9. The salinization of these waters results essentially from the dissolution of evaporites (gypsum in particular), infiltration of runoff water, intensive pumping, evapotranspiration and possible contamination by the infiltration of irrigation water. The leaching by rainwater and irrigation water of elements accumulated in the unsaturated zone constitutes an important contribution of salts. Another potential source of salinization can be attributed to the saline marls of the Miocene, with which the waters of the Plio-Quaternary aquifer are in contact. The results for the Isly basin are in agreement with those obtained by Nouayti et al (2015) [12] in high basin of Ziz.

\section{Conclusion}

The application of hydro-chemical methods coupled with statistical methods showed a significant relationship between different chemical elements in the thirteen stations studied. As a result, the degradation of water quality in the Isly aquifer is due to geological, atmospheric and anthropogenic factors, bearing to mind that groundwater is more sensitive when the upper part of the water table is closer to the surface and the rock increases the permeability of the aquifer.

\section{References}

1. F. Mortier, T. Nguyen Quang, M. Sadek, Service des Ressources en Eau de l'Office National des Irrigations du Maroc. 327-333 (1967)

2. D. El Hafid, Z. Zerrouqi, B. Akdim, Larhyss Journal, 83-94 (2017)

3. M. Oujidi, Ph.D. Thesis, Université d'Oujda, 277 (1994)

4. M. Rakus, Mines Géologie \& Energie Rabat 46,75-78 (1979)

5. A. Pique, A. Michard, Am. J. Sci, 289, 286-330 (1989)

6. A. Torbi, J.P. Gélard, C.R. Académie des Sciences Paris, 330, 853-858 (2000)

7. C. Hoepffner, A. Soulaimani, A. Piqué, J Afr Earth Sci. 43, 144-165 (2005)

8. A. Michard, Notes et Mem. Serv Géol Maroc. 252, 408 (1976)

9. G. Cattaneo, Unpub.Thesis, University of Bourgogne, Dijon, 300 (1987)

10. M. Simonot, J.P. Thauvin, Notes et Mémoires du Service géologique du Maroc, 242, 233-242 (1971)

11. S. Adams, R. Titus, K. Pietersen, G. Tredoux, C. Harris, J. Hydrol. 241, 91-103 (2001)

12. N. Nouayti, D. Khattach, M. Hilali, J Mater Environ Sci, 6, 1068-1081(2015) 